\title{
The Significance of English Proficiency in Reforming Nigerian Education and Society
}

\author{
Matthew Rudd, \\ University Lecturer, Mahanakorn Univeristy of Technology, Bangkok, Thailand
}

\begin{abstract}
This paper presents an initial overview of Nigeria's education system and the significance of English therein. To extend the scope, this essay will also draw further comparisons of English proficiency levels with neighbouring countries to help determine the extent to which English language proficiency can be indicative of a nation's level of education. Thirdly, this paper contemplates the prospect of improving English proficiency through education reforms that centre on vocational training, and, improving access to English language learning in a bid to help minimise the inherent societal imbalances and social precariousness.
\end{abstract}

Keywords: Education, English, proficiency, reform

DOI: $10.7176 /$ JAAS/56-06

Publication date:June $30^{\text {th }} 2019$

\section{Introduction}

Akin to most countries, local authorities take responsibility for overseeing the implementation of state-controlled policy for public education and state schools in Nigeria. However, since declaring independence from the U.K, Nigeria's central government has been dominated by instability and a definite framework for education policies has not been determined. As a matter of concern, Nigeria is home to the largest population of out-of-school youth in the world, amounting to over 10.5 million (Abdullahi \& Abdullah, 2014).

The Universal Basic Education Commission (UBEC) and has made education "free", "compulsory" and a right of every child. The UBEC law section 15 defines UBE as early childhood care and education, stipulating access to 9-years formal schooling, adult literacy and non-formal education, skill acquisition programs, and the education of all groups of society including nomads, migrants, girls, children, street children, disabled people and women (Aderinoye, 2007). Typically, in most developing countries, schools often implement their own individual curriculum and set their own examination criteria in the absence of a standardised curriculum. In Nigeria, high school examinations are moderated externally to maintain a consistency of grading standards, the Senior Secondary School Examination (SSCE) is administered by the West African Examination Council (WAEC).

Although education in Nigeria is free in state-owned institutions, students struggle to secure the financial means to purchase their own learning materials such as books, stationery and uniforms which usually cost fifty thousand naira (\$200) per academic year (UNESCO-IBE. 2011). Additional issues surrounding recruitment and retention of teaching staff who are legally qualified, thus in possession of a National Certificate of Education and a bachelor's degree, result in many secondary schools in Nigeria being understaffed due to insufficient budgets, the lack of incentives offered to teachers, and, inconsistent (often incomplete) payment of salaries. Regrettably, the option of private education in Nigeria is inaccessible to the majority of working-class families, as annual tuition fees range from $250,000-1,000,000 \mathrm{Naira}(\$ 1000.00=\$ 4,000.00 \mathrm{USD})$, which is not financially viable prospect for most household budgets.

The role of English in education

In most developing nations, core subjects are taught in the local language. In Nigeria, however, core subjects (mathematics, economics, civic education, biology, chemistry, physics, history, geography and social studies) are taught exclusively in English. Furthermore, proficiency of English is an indispensable precondition for securing admission into any Nigerian university and remains the lingua franca used for the teaching of all school subjects, except for the teaching of local languages (Afolayan, 1984). English is also used as the lingua franca from grassroots including pre-school until post-secondary school, as well as for vocational subjects (UNESCO, 2011). Nigerian society tends to deeply embrace the use of English given its importance as a unifying means of communication; which in the case of Nigeria unites people from all corners of the country encompassing the diverse range of tribes and ethnic groups. English also forms the basis the judicial and legal framework and is used universally in state media broadcasting, politics and businesses (Elugbe \& Omamor, 1991).

English proficiency in education and its predictive value

An increasingly large body of research has linked English proficiency levels to higher academic attainments in non-language related subjects. More specific to the context of this essay however, the Journal of Scientific Research (2009, pp.490-495) reviewed the implementation of English in Nigerian schools, and measured the English proficiency of 200 Nigerian secondary school students (109 males and 91 females) from eight random 
schools in Oyo and Osun states (four schools in each state). The study reviewed the correlation between students' English language skills, and how their proficiency predicts overall academic performance. Students underwent an English Language Proficiency Test (ELPT- a standardised TOEFL paper) to gauge students' listening, reading comprehension, grammar and writing skills. The assessment also included an interview to test the students' speaking skills, taking account of pronunciation, style, vocabulary, grammar, syntax, fluency and accuracy. Following the ELPT test results, the students' level of English was categorised as follows:

- Only 4\% of the sampled students failed the proficiency in English test (less than 40\%)

$-21.5 \%$ had ordinary pass $(40-49 \%)$

$-43 \%$ had lower credit $(50-59 \%)$

- 26\% had upper credit (60-69\%)

- $6.5 \%$ had distinction $(70-79 \%) 5$

The mean value of the students ELPT score was $58.2 \%$, which showed that the students' proficiency of English was above average. After which, the academic achievement scores of the participants were collected across three core subjects: English, mathematics and biology. Linear regression analysis was utilised in order to determine the relationship between the three performance variables to measure the correlative impact of English language proficiency on students' overall academic achievement.

Statistical analyses revealed that there was a significant positive relationship between proficiency in English language and academic performance $(r=0.499 ; \mathrm{p}<.05)$. The positive relationship implied that the more proficient students are in English, the better their academic performance as a whole. The dependent variable revealed that the coefficient of determination (Adjusted $\mathrm{r} 2$ ) $=0.408$ ), which gives the proportion of variance to be $40.8 \%$, means that $40.8 \%$ of the total changes in student's academic performance is determined by the level of the students' proficiency in English. The effect is therefore shown to be significant $(\mathrm{F} \mathrm{1,198)}=18.0 ; \mathrm{p}<.05)$.

Seeing that $41 \%$ of the variation in students' performance is determined by students' proficiency in English Language, the paper deduced that English language proficiency in Nigeria is a reliable indicator of academic performance of senior secondary school students. The author of the paper recommended that educating Nigerian (ESL) learners to acquire enhanced English proficiency skills should be seen as a priority by the government administration, as English language proficiency ultimately determines overall academic success.

The significance of improving English proficiency

A more educated population can add value to human capabilities and bring the country forward enhancing Nigerians competitive stance on the global scene. This would, however, require a coordinated effort from all stakeholders in the education sector in Nigeria such as curriculum planners, text book publishers, English language educators and also to consider the prospect of vocational training programmes through use of English.

Based on the finding in the report above, English language (especially in terms of active macro skills capacities: written and spoken form), should be given special attention at all levels within the Nigerian educational system in view its importance in optimising academic performance, and thus equipping individuals with life skills. English language teachers in Nigeria could be provided regular revision courses to avoid language attrition and to maintain instructional capabilities to clinically impart the four macro skills writing effectively at secondary school levels.

According to the English Proficiency index, Nigeria is ranked second out of the nine African countries featured, second to only South Africa (another former British colony). The latter admittedly has a larger education budget per capita $(\$ 12,870$; more than double), and a quarter of the population size to govern ( $54.3 \mathrm{~m}$ compared to $186 \mathrm{~m})$. In view of the fact that Nigeria has the smallest budget allocation per head among all the countries listed below, and has the largest population to manage, it appears to make reasonable use of its resources to achieve commendable proficiency.

Table 1: Africa at a Glance - English Proficiency Index (2018)

\begin{tabular}{|c|c|c|c|c|c|c|}
\hline Country & Score & Rank / 88 countries & Male & Female & Population & GNI per capita \\
\hline South Africa & 66.52 & 6 & 64.73 & 67.85 & $54.8 \mathrm{~m}$ & $\$ 12,830$ \\
\hline Nigeria & 56.72 & 29 & 56.05 & 58.23 & $190.6 \mathrm{~m}$ & $\$ 5,740$ \\
\hline Egypt & 48.76 & 62 & 48.12 & 50.50 & $97.04 \mathrm{~m}$ & $\$ 10,980$ \\
\hline Morocco & 48.10 & 67 & 46.44 & 50.50 & $33.9 \mathrm{~m}$ & $\$ 7,710$ \\
\hline Algeria & 44.50 & 81 & 44.33 & 46.50 & $40.9 \mathrm{~m}$ & $\$ 14,390$ \\
\hline
\end{tabular}

Another matter worthy of remark is that the English Proficiency Index website publicised the difference between gender; and as seen above, women appear to outperform their male counterparts in every nation. Given that English proficiency can be perceived as a means of predicting academic capabilities, the question that remains is that women are largely underrepresented in education, the workplace and suffer from societal constraints hindering their development and potential fulfilment; this will be discussed in the next section. 


\section{Constraints to administrative development}

Lamentably female students still face greater restrictions accessing education, despite their innate superior linguistic capabilities (see table 1), which as discussed, enhanced performances in English seem naturally transferrable to non-language related subjects.

Over the preceding decades, enrolment of girls in primary education progressively increased from $30 \%$ to as high as $80 \%$ between 1970 and 1994, (Chuta, 1986); however, differences persist between the enrolment of males and females in all tiers of education. The combined gross enrolment for primary, secondary and tertiary schools for female was $57 \%$ compared to $71 \%$ for males (Omolewa, 2008), and, the percentage of female workers employed in key professions are (under)represented as follows: architects $2.4 \%$, quantity surveyors $3.5 \%$, lawyers $25.4 \%$, lecturers $11.8 \%$, gynaecologists $8.4 \%$, paediatricians $33.3 \%$ and media practitioners $18.3 \%$. In Nigeria, the current female adult literacy rate (ages 15 and above) is $59.4 \%$ compared to $74.4 \%$ for men, and according to Omole (1998), and it is differences in education that have led to this gap in literacy. The Central Bank of Nigeria publicised that the gender gap in literacy rates in rural areas is more prominent (18.3 per cent), although, currently among young learners (6-9 years), encouragingly the gap has narrowed to only 3.9 per cent in favour of boys.

In the Appraisal report "Skills Training and Vocational Education Project" (Federal Republic of Nigeria, 2005), Nigerian researcher Obasi (2003) identified a host of constraints with 'Nigerian tradition' being named as top of the list. The 'Nigerian tradition' still attaches higher value to a man than a woman, and the long-held belief that in Nigerian culture male superiority prevails, and as a result, so does female subordination. The Nigerian society has inherent cultural practices that restrain women's emancipation and thus curtail their progress; such practices include early / forced marriage, wife-inheritance and widowhood (Bolarin, 1987). Given the parental preference to boys, Nigerian parents are known to invest in children according to gender, and quite often, the family only have the financial means to send one child to school (Akpoigho, 1999).

According to UNESCO, (2008 - "Education for All by 2015: Will we make it?), improving women's' access to education could also result in better childcare, helping to ensure children are immunised, receive adequate nutrition and follow proper sanitation practices; which would naturally result in higher infant survival rates. The International Center for Research on Women adduced that the education that a girl receives is the strongest predictor of the age she will marry, and is a critical factor in reducing the prevalence of child marriage (Saranga \& Kurz 2006).

The World Bank estimates that an additional year of schooling for 1,000 women helps prevent two maternal deaths NICEF (State of the Worlds' Children, 2004). Literacy rates are considered as a crucial measure to enhance a region's human capital, as policy analysts estimate that literate people can be trained less expensively than illiterate people, have a higher socio-economic status, enjoy better health and employment prospects (Kutner et al., 2003). Policy makers also posit that higher literacy for women increases job opportunities and access to higher education (UNESCO 2004). Elaborating further, Ojo (2002) warns that, "although it is often viewed that a woman working in the home benefits her family, it puts a strain on the whole community as education is one of the keys to success and being able to prosper.

Dr. Robert Limlim (2008), UNICEF's deputy representative clarified the state of affairs when summarising that "For Nigeria to achieve the goal of being among the largest 20 economies in the world, she must rapidly educate the children, most of all, the girls." Limlim (2008) also posits that educating girls is known to be the basis for sound economic and social development, given that education can produce more mothers, who can in turn educate their children and provide care for their families.

Actions to drive change

A steady trend of progress has been well observed over the recent decades seeing that among persons aged 15 to 19 years, the literacy rate is now $70 \%$; in contrast to previous inferior literacy rates of merely $13 \%$ observed among persons 80 years or older. Likewise, the gap between boys and girls aged 15 to 19 is narrowed to a less salient $11 \%$ (Huebler, 2008).

Further to improving literacy, the Nigerian government pledged to offer technical and vocational education through a number of commissions and programs (Obasi, 1997). Vocational training and informal education came into practice in the early 1980's as a result of high unemployment rates for school graduates, in response to which a government initiative aimed at creating vocational programmes available to students. The most substantial plan for improvement was the Master Plan for 2001-2010 developed by the Federal Ministry of Education in 2000. The Nigerian government also incentivised apprenticeships programmes, and carefully enforced child labour laws prohibit children younger than 15 from entering the workplace, although children less than 15 years of age may legally join apprenticeship programmes.

Nonetheless, current challenges to adequately introduce these systems include a shortage of teachers, failure to understand the labour market trends, and, out-dated curriculum / technology at vocational training centres. Moreover, many policies aimed at improving vocational training have been repeatedly blocked by a small number of politicians, causing many academics to question whether politicians are attempting to purposely subjugate the 
working class through a lack of educational reform; and, or, whether corruption and self-interest from elite politicians has hampered the administration of this policy. Illiteracy rates in Nigeria have been significantly linked to the government's lack of commitment towards its standardised education policies (Schultz, 2002), as an overall lack of funding and over-centralisation have significantly hindered the quality, financing, and, implementation of literacy programs.

\section{Conclusions}

For Nigeria to efficiently enforce administrative polices to eradicate illiteracy, promote gender equality and to improve vocational training to enhance the mobility of its workforce; more accountability and transparency are required on behalf of politicians, detailing how funds generated from major export sources are utilised and where they are to be allocated; especially as Nigeria is the world's eighth largest exporter of crude oil averaging 2.28 million barrels per day with a total of 37.2 billion barrels of proven oil reserves, ranking the country as the largest oil producer in Africa and the 11th largest globally (US Energy Information Administration, 2011).

Even though the Nigerian government and various NGOs have introduced community-wide strategies to increase literacy rates among both children and adults; the elimination of stereotyped roles applying to women especially, may be brought about by adapting curricular and teaching methods to challenge traditional assumptions and viewpoints. The eventual full integration of women in education and equal rights in the labour market would be far-reaching step forward. Not just because of their contribution to domestic productivity, but also due to the naturally higher English proficiency levels that have been noted among women (in all the African countries hitherto discussed), and as this paper has helped clarify, English proficiency has also been typified as a reliable indicator of academic performance in broader terms.

Therefore, improving women's access to education should not only help to eradicate illiteracy (whether it be their respective role as a teacher, and / or a mother), but also create potentially talented assets beneficial to society in both public and private sectors; increasing the provision of skilled human resource to bring the country forward.

\section{References}

1. Abdullahi, D., Abdullah, J. (2014). The Political Will and Quality Basic Education in Nigeria. Journal of Power, Politics, and Governance. American Research Institute for Policy Development. 2 (2): pp. 75100.

2. Afolayan, A. (1984). Journal of Multilingual and Multicultural Development. 5 (1): African Development Fund.

3. Bolarin, T. A. (Autumn 1987). Girls and Science Education in Nigeria. The Journal of Negro Education. 56 (4): pp. 580-587.

4. Chuta, E.J. (1986). Free Education in Nigeria: Socioeconomic Implications and Emerging Issues. Comparative Education Review. 30 (4): pp. 523-531.

5. Akpoigho, C. (1999). Incorporating AIDS Education in Prison Adult Education Programs in Nigeria. Journal of Correctional Education. 50 (3): pp. 96-10.

6. Elugbe, B., Omamor, A. (1991). Nigerian Pidgin, Phonology.

7. Huebler, F. (2008) Adult Literacy in Nigeria. International Education Statistics.

8. Journal of Women in Culture and Society. (2003). Women's Education: A Global Challenge. 29 (2): pp. $325-355$

9. Journal of Scientific Research. (2009). English Language Proficiency as a Predictor of Academic Achievement among EFL Students in Nigeria". pp. 490-495.

10. Kutner, M., Greenberg, G., Jin, Y., Boyle, B., Hsu, Y., Dunleavy. E. (2003). Literacy in Everyday Life: Results from the 2003 National Assessment of Adult Literacy.

11. National NDP. (2005). Human Development Report. New York, University Press.

12. NICEF. (2004). State of the World's Children.

13. Obasi, E. (1997). Structural adjustment and gender access to education in Nigeria. Gender and Education, 19: pp. 161-177.

14. Ojo, A. (2002). Socio-Economic Situation in Africa Atlases (Nigeria), Paris-France, Les Editions J.A., pp. 126-127.

15. Omole, L. (1998). The politics of workers' education in Nigeria. International Journal of Lifelong Education. 17 (5): pp. 291-306.

16. Omolewa, M. (2008). Adult literacy in Africa, the push and pull factors. International Review of Education.

17. Saranga, S., Kurz, K. (2006). ICRW research on prevalence and predictors of child marriage in developing countries.

18. Schultz, T.P. (2002). Why Governments should Invest More to Educate Girls. World Development, 30 (5): pp. $207-225$. 
18. Skills Training and Vocational Education Project (2005). Appraisal Report. Federal Republic of Nigeria.

19. U.S. Diplomatic Mission to Nigeria (2010). Nigeria Education Profile.

20. UNESCO (2004). The Plurality of Literacy and its Implications for Policies and Programs.

21. UNESCO (2008). Education for All by 2015: Will we make it? Global Monitoring Report.

22. UNICEF (2008). UNICEF and Partners Launch Girls' Education Initiative in Nigeria.

23. UNESCO-IBE. World data on Education. (2011). Retrieved 24 July 2014.

24. US Energy Information Administration (2011). Country Analysis Briefs. Retrieved 2012-07-10. 